\title{
New species and synonymies in Hexoplonini Martins, 2006 (Coleoptera, Cerambycidae), with notes and new records on Cerambycinae Latreille, 1802
}

\author{
Francisco Eriberto de Lima Nascimento ${ }^{1,2}$ \& Antonio Santos-Silva ${ }^{1,3}$ \\ 1 Universidade de São Paulo (USP), Museu de Zoologia (MZUSP). São Paulo, SP, Brasil. \\ 2 ORCID: 0000-0002-5047-8921. E-mail: eribnascimentofl@gmail.com (corresponding author) \\ 3 E-mail: toncriss@uol.com.br
}

\begin{abstract}
Glyptoscapus letiziae, a new species of Hexoplonini Martins, 2006, is described from Brazil (Minas Gerais). Glyptoscapus cicatricosus Aurivillius, 1899 and G. vanettii Martins, 1959 are synonymized with G. pallidulus (White, 1855). A key to species of Glyptoscapus is provided. New state records are presented for Thoracibidion io (Thomson, 1867) (Neoibidionini), Coleoxestia rafaeli Santos-Silva \& Wappes, 2017 and C. denticornis (Gahan, 1892) (Cerambycini). The female of C. rafaeli is described for the first time.
\end{abstract}

Key-Words. Key; Southern Brazil; South America; Taxonomy.

\section{INTRODUCTION}

Recently, during the process of introduction of specimens in to the MZSP (Museu de Zoologia, Universidade de São Paulo, São Paulo, São Paulo, Brazil), collection we found a new species of Hexoplonini Martins, 2006, belonging to the genus Glyptoscapus Aurivillius, 1899.

Hexoplonini (Cerambycinae) is currently composed of 150 species in 22 genera (Tavakilian \& Chevillotte, 2017). According to Martins $(1967,2006)$, only two genera of Hexoplonini have a cicatrix at the apex of the scape: Glyptoscapus and Glyptoceridion Martins, 1959. The former differs from the latter by the very long third antennomere, which is usually twice as long as antennomere IV (shorter than IV in Glyptoceridion), pronotum not microsculptured (microsculptured in Glyptoceridion) and elytra not remarkably depressed on the central dorsal area (remarkably depressed in Glyptoceridion). Currently, Glyptoscapus includes five species distributed only in South America (Monné, 2018).

We also found a specimen of Thoracibidion io (Thomson, 1867), several specimens of Coleoxestia rafaeli Santos-Silva \& Wappes, 2017, and Coleoxestia denticornis (Gahan, 1892), collected in Brazilian states in which they were not previously registered. Additionally, we are describing the female of $C$. rafaeli for the first time.

\section{MATERIAL AND METHODS}

Photographs were taken with a Canon EOS Rebel T3i DSLR camera (Taiwan), Canon MP-E
$65 \mathrm{~mm} \mathrm{f} / 2.8$ 1-5X macro lens, controlled by Zerene Stacker AutoMontage software. Measurements were taken in millimeters $(\mathrm{mm})$ using measuring ocular Hensoldt/Wetzlar - Mess 10 (Germany) in the Leica MZ6 stereomicroscope (Germany), which was also used in the study of the specimens.

The references concerning Glyptoscapus and its species are restricted to their original descriptions, Monné (2018) and Tavakilian \& Chevillotte (2017). The photography of the Holotype of G. pallidulus was adopted from Bezark (2018). A complete list of references for them is available in these two catalogues. The morphological terms used follow Lawrence et al. (2010).

\section{RESULTS \\ Cerambycinae \\ Hexoplonini Martins, 2006 \\ Glyptoscapus Aurivillius, 1899}

Glyptoscapus Aurivillius 1899: 264; Monné (2018): 439; Tavakilian \& Chevillotte (2017).

Remarks: Aurivillius (1899) described Glyptoscapus for his new species G. cicatricosus, from Brazil. According to him (translated): "Femora elongate, sublinear, mesofemora with long spine at outer apex and very short spine at inner apex, metafemora with long spine at outer apex and short at inner apex". However, the drawing in the original description shows that the mesofemora have long spine at the inner apex, and not at the outer apex. Martins (1959) had already report- 
ed this error (translated): "Apparently, Aurivillius makes a mistake here in his generic diagnosis, affirming to be long the spine at the "outer" apex of the mesofemora".

\section{Glyptoscapus pallidulus (White, 1855)} (Figs. 8-16)

Ibidion pallidulum White, 1855: 234.

Gnomidolon (?) pallidulum; Lacordaire, 1868: 331

Glyptoscapus pallidulus (White, 1855); Monné (2018): 440; Tavakilian \& Chevillotte (2017).

Glyptoscapus cicatricosus Aurivillius, 1899: 264; Monné (2018): 440; Tavakilian \& Chevillotte (2017). Syn. nov. Glyptoscapus vanettii Martins, 1959: 270; Monné (2018): 440; Tavakilian \& Chevillotte (2017). Syn. nov.

Remarks: White (1855) described Ibidion pallidulum Brazil (Pará), but did not mention the cicatrix at the apex of the scape. According to him, "...femora with two spines at the apex, the outer larger..." Evidently, White (1855) was writing about the meso- and metafemo$\mathrm{ra}$, since the profemora never have spines at the apex. Martins (1967) correctly transferred Gnomidolon pallidulum to Glyptoscapus and reported (translated): "It differs from cicatricosus by the presence of only two longitudinal rows of piliferous punctures on each elytron, by the apical spines of the elytra shorter and by the armature of the femora. The mesofemora in G. pallidulus have an inner tab slightly acute, not projected in developed spine as occurs in cicatricosus, and the outer spine of metafemora is also, comparatively, much shorter".

Martins (1959) described G. vanettii, differing it from G. cicatricosus by the inner spine of the mesofemora shorter, the legs and antennae of the same color of the body, and the abdomen unicolorous, while in G. cicatricosus the legs are flavous, and the abdominal ventrite I is lighter. Later, Martins (1967) reported the following differences (translated): "Glyptoscapus vanettii differs from G. cicatricosus by the general color reddish-orange; scape relatively more elongate and less thick; carinae of basal antennomeres (16x) more evident; sexual punctation of prosternum of males (I saw only a specimen of this sex) less abundant; presence of only two rows of erect setae on each elytron; anterior macula of elytra less developed; smaller inclination of the elytral band, and by the apex of mesofemora only acute, not spinose". Martins (1967) differentiated G. pallidulus from G. vanettii only by the shape of the elytral maculae, and color of antennae, elytra and legs.

According to Martins (2006) (translated): "Although having general color similar to G. cicatricosus, G. pallidulus differs by the shape of mesofemora. The apical tabs are only projected, while in G. cicatricosus the apex of mesofemora has long spine at inner side. Another characteristic that differs these species from each other is the number of longitudinal rows of setae on middle of the elytra; G. pallidulus has only two dorsal rows, while G. cicatricosus has five rows, two lateral and three dorsal".

Actually, all features pointed out to differentiate G. cicatricosus, G. pallidulus, and G. vanettii (general color, color of the head and pronotum, length, ratio and shape of spines of meso- and metafemora, number of rows of the elytral setae, etc.) are extremely variable (Figs. 8-16). This variability makes it evident that the three are a single, variable species. Even the specimens deposited in the MZSP collection, identified as G. cicatricosus, G. pallidulus, and G. vanettii, do not fully agree with all descriptions and redescriptions of each species, making it difficult to separate these three species. Curiously, one of the paratypes of $G$. vanettii was later identified as G. pallidulus by Martins (1967). Thus, based on comparison among a reasonable number of specimens belonging to MZSP collection, we are formally synonymizing Glyptoscapus vanettii and G. cicatricosus with G. pallidulus.

Material examined (all from MZSP): COLOMBIA, Magdalena: Cacagualito, 1 male, V.1999. PERU, San Martín: Tarapoto, 1 female, X-XII.1885, M. de Mathan col. Junín: Satipo, holotype and paratype females of $G$. vanettii, 1938. BRAZIL, Amazonas: Manaus (campus universitário), 1 male, 04.VI.1982, J.A. Rafael col. Pará: Santarém, paratype of G. vanettii; Marituba, 1 male, 10.VI.1961, Bechyné col. Goiás: Jataí (Faz. Aceiro), 1 male, X.1962, Exp. Dep. Zool. col.; 1 female, XII.1997-I.1998. Bahia: Cachimbo, 1 female, C.H. Pujol col.; Vila Victoria, 1 male, 2 females, 1890, C.H. Pujol; Vila Victoria to Cachimbo, $1 \mathrm{fe-}$ male, 1890, C.H. Pujol col.; from Santo Antonio da Barra to Vila Victoria, 2 females, C.H. Pujol col; Itapetinga, 1 female, XI.1969, F.M. Oliveira col. Espírito Santo: Linhares (Parque Sooretama), 1 male, 1 female, XI.1962, F.M. Oliveira col.; 1 male, X.1963, F.M. Oliveira col; Corrego Itá, 1 male, XI.1956, W. Zikán col. São Paulo: Iporanga, 1 female, I.XI.1961, Lenko \& Reichardt col.; Itanhaém, 1 female, 28.XII.1978, Fontes \& Terra col.; 1 female, 27.XII.1956, Martins \& Amante col.; São Paulo (Morumbi), 1 female, II.1948, Dirings col.; 1 female, I.1952, Dirings col; (Jabaquara), 1 male, XI.1941, Dirings col.; (Saúde), 1 female, I.1922; 1 female, 28.XI.1916; Santo Amaro, 1 female, XII.1941, Dirings col.; 1 female, III.1942, Dirings col.; Botucatu, 1 female, III.1967, Dirings col.; São Roque, 1 female, 25.XII.1971, F. Lane col. ARGENTINA, Misiones: Santa Maria (Dep. Concepción), 1 female, X.1946, M.J. Viana col.

\section{Glyptoscapus bivittatus Gounelle, 1909 (Figs. 5-7)}

Glyptoscapus bivittatus Gounelle, 1909: 660; Monné (2018): 439; Tavakilian \& Chevillotte (2017).

Remarks: Gounelle (1909) described Glyptoscapus bivittatus based on a single specimen from Brazil (Minas Gerais, Serra do Caraça). According to him (translated): "The yellow lateral band that adorns each elytron begins at the humerus and extends to the posterior third; its inner edge describes parallel to the suture a very long arc". According to Martins (1967), who examined the holotype and two specimens also from Serra do Caraça, the yellow macula on the elytra has a somewhat variable 
length, since in one of the specimens examined by him it reaches only the middle of the elytra. Martins (2006) reported (translated): "So far, Glyptoscapus bivittatus is only recorded from two mountain ranges (Serra do Caraça and Serra do Cipó), members of the Serra do Espinhaço in Minas Gerais, from Ouro Preto in Minas to Juazeiro in Bahia". However, we do not know who recorded Serra do Cipó, because the only specimens previously recorded were from Serra do Caraça, and the specimen recorded in Martins (2006) is from Santa Barbara, a city very near to Serra do Caraça and, in a straight line, about $80 \mathrm{~km}$ from Serra do Cipó.

Despite the comments by Gounelle (1909) and Martins $(1967,2006)$ regarding the shape of the elytral macula, actually, it can be considerably different, as it is possible to see at Bezark (2018). In this specimen the distal area of the macula is projected toward middle of the elytra as a transverse band. The single specimen belonging to MZSP collection (Fig. 5) agrees very well with one of the specimens examined by Martins (1967), because the macula reaches only the middle of the elytra. There is no doubt that these two specimens (Fig. 5, and that figured in Bezark 2018) belong to the same species. Notwithstanding, these two specimens have the basal half of the elytra mostly dark brown, and the distal half reddish-brown. Neither Gounelle (1909) nor Martins $(1967,2006)$ commented on elytral coloration.

As both, G. bivittatus and G. flaveolus, have the elytral apex not whitish (see dilemma 1 of the key) and because we know that the head color is very variable in G. cicatricosus, a feature used to distinguish $G$. flaveolus from its congeneric (this variation may or may not occur in these species), we do not know which are the true differences between those two species, because we did not examine specimens of $G$. flaveolus. According to Bates (1870) on the distal area of the elytra in G. flaveolus: "apex sometimes becoming dark". Martins (1967), who examined the two syntypes of G. flaveolus, reported (translated): "The head of the holotype [sic] is dark brown, and there is a more or less brownish area behind the posterior elytral macula, with indefinite limits. In the paratype, which is lighter, the head still shows some darkened areas. I saw a specimen with the head and posterior area of the elytra black".

For the time being, we consider the darkened area on the elytral apex in G. flaveolus (darker than on basal area) as a distinguishing feature to separate $G$. flaveolus from G. bivittatus since, apparently, in the latter, the apical area of the elytra is slightly lighter than on basal area.

Material examined: BRAZIL, Minas Gerais: Estação Ambiental de Pati-CEMIG, 1 male, 07.XII.1986, A.B. \& A. Machado col. (MZSP).

\section{Glyptoscapus letiziae sp. nov.} (Figs. 1-4)

Description: Female: Head dark brown, almost black; mouthparts yellowish-brown except brownish last max- illary and labial palpomeres; scape dark brown; pedicel dark brown basally, gradually reddish-brown toward apex; antennomeres III-XI pale yellow, very slightly darkened at apex; prothorax, and ventral side of meso- and metathorax black (more dark brown on some areas); legs pale yellow, more brownish on some areas, especially apex of femora, base of tibiae and parts of tarsi; abdominal ventrites I-III dark brown, almost black; abdominal ventrite IV dark brown basally, gradually dark reddish-brown toward apex; abdominal ventrite $\mathrm{V}$ dark reddish-brown basally, gradually light reddish-brown toward apex; elytra black, gradually dark brown toward distal area, except: longitudinal, slightly oblique light yellowish-brown macula, placed at about center of dorsal surface from a little before apex of basal quarter to a little after apex of basal third; slightly curved light yellowish-brown band placed on dorsal surface of central third, from suture to lateral curvature; yellowish-white distal area.

Head: Frontal plate slightly convex, rounded close to clypeus, triangularly narrowed toward vertex; smooth except for a few punctures toward its narrowest area; frontal area under antennal tubercles with subtriangular depression (narrowed toward clypeus). Area from between antennal tubercles to almost middle of frontal plate with well-marked inverted V-shaped sulcus; frons with minute, sparse whitish setae close to lower eye lobes, and a few, almost indistinct setae centrally. Vertex depressed, microscopically, densely punctate between antennal tubercles and upper eye lobes; with minute, sparse whitish setae; remaining surface nearly smooth with a few shallow punctures interspersed (slightly rugose close to prothorax); with minute, sparse whitish setae interspersed with a few short, nearly erect white setae. Area behind upper eye lobes smooth close to eye, slightly rugose close to prothorax; with minute, sparse whitish setae on smooth area, glabrous on remaining surface. Area behind lower eye lobes tumid, coarsely, sparsely punctate close to eye, nearly smooth on remaining surface; with long, erect, sparse yellowish-white setae on tumid area, glabrous on remaining surface. Genae finely, sparsely punctate toward dorsal side, more abundantly punctate toward ventral side, except smooth distal area; with minute, sparse golden setae except glabrous distal area. Antennal tubercles somewhat elevated, with rounded apex, abruptly inclined toward upper eye lobe; minutely, sparsely punctate; with minute, sparse white setae. Median groove distinct from apex of frontal plate to area between antennal tubercles. Postclypeus with transverse, fine carina near frontal plate; with fine puncture on each side, from which emerges a long, erect yellowish-brown seta. Labrum coplanar with anteclypeuson basal half, inclined on distal half; with short, sparse yellowish-white setae, one long, erect golden seta on each side, and fringe of golden setae at distal margin. Gula mentum smooth, glabrous from prothoracic margin to level of tumid area behind lower eye lobes, transversely rugose-punctate, with long, erect, sparse yellowish-white setae between upper eye lobes. Upper eye lobes with 3 rows of ommatidia (only 


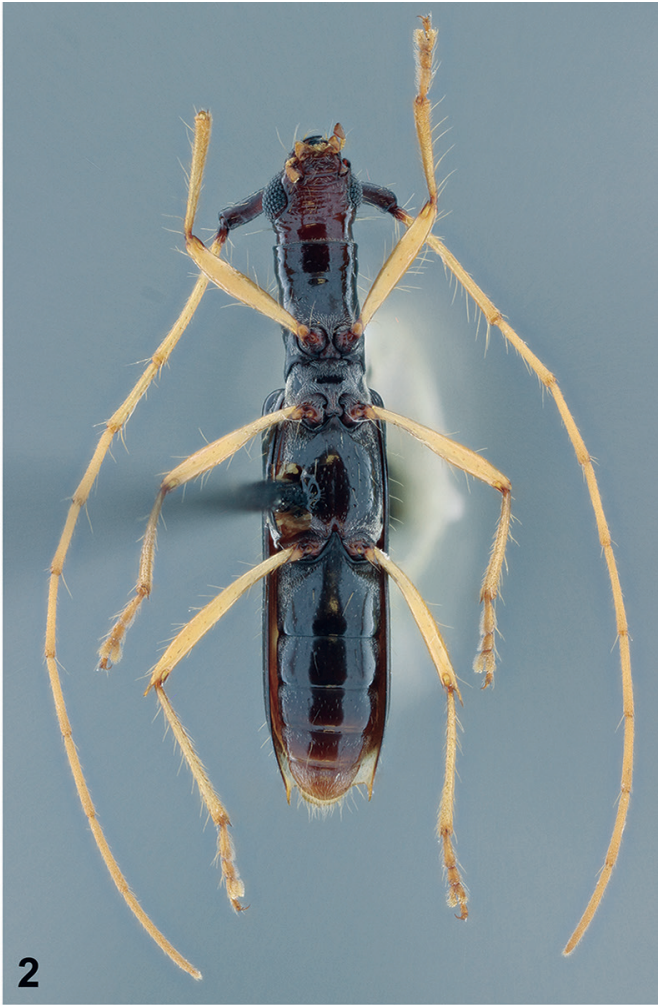

1
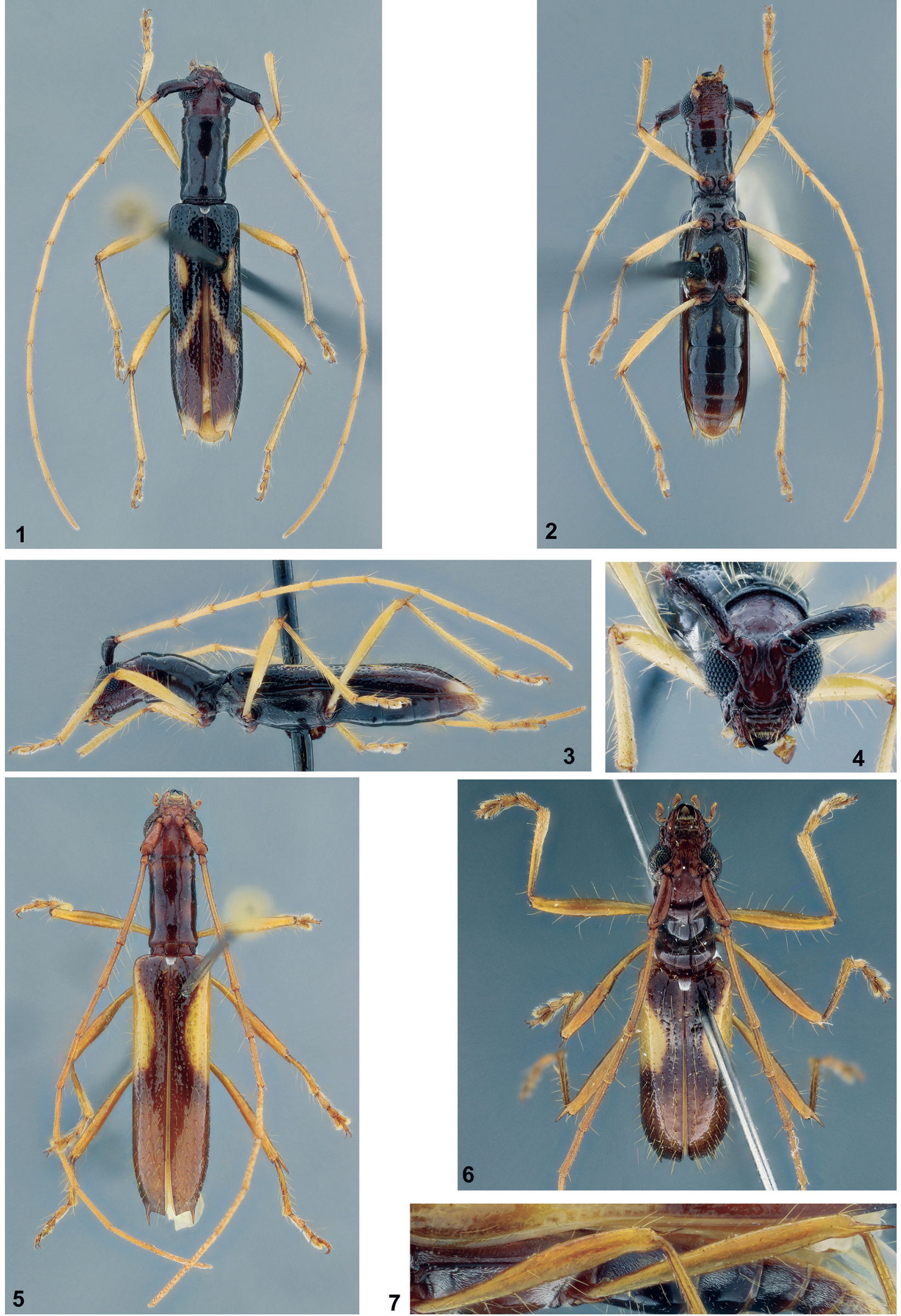

3
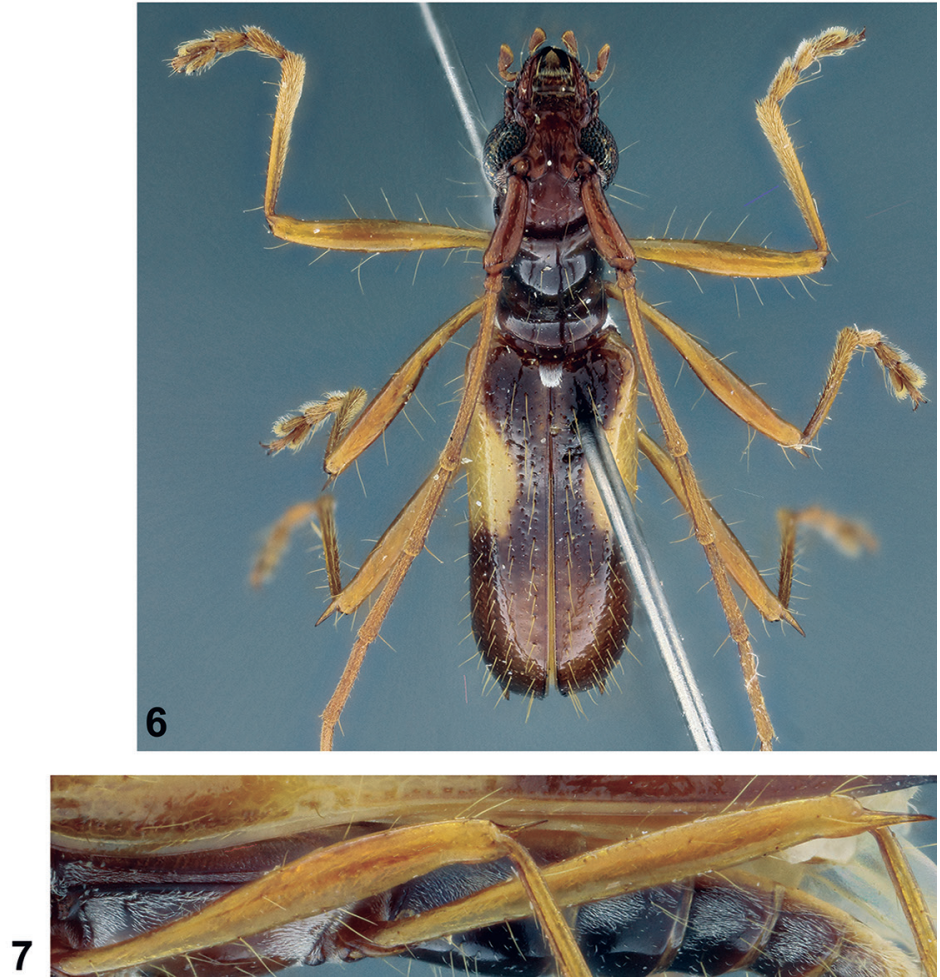

Figures 1-7. (1-4) Glyptoscapus letiziae sp. nov., holotype female: (1) Dorsal habitus; (2) Ventral habitus; (3) Lateral habitus; (4) Head, frontal view. (5-7) Glyptoscapus bivittatus: (5) Dorsal habitus; (6) Dorsal habitus, anterodorsal view; (7) Meso- and metafemora. 

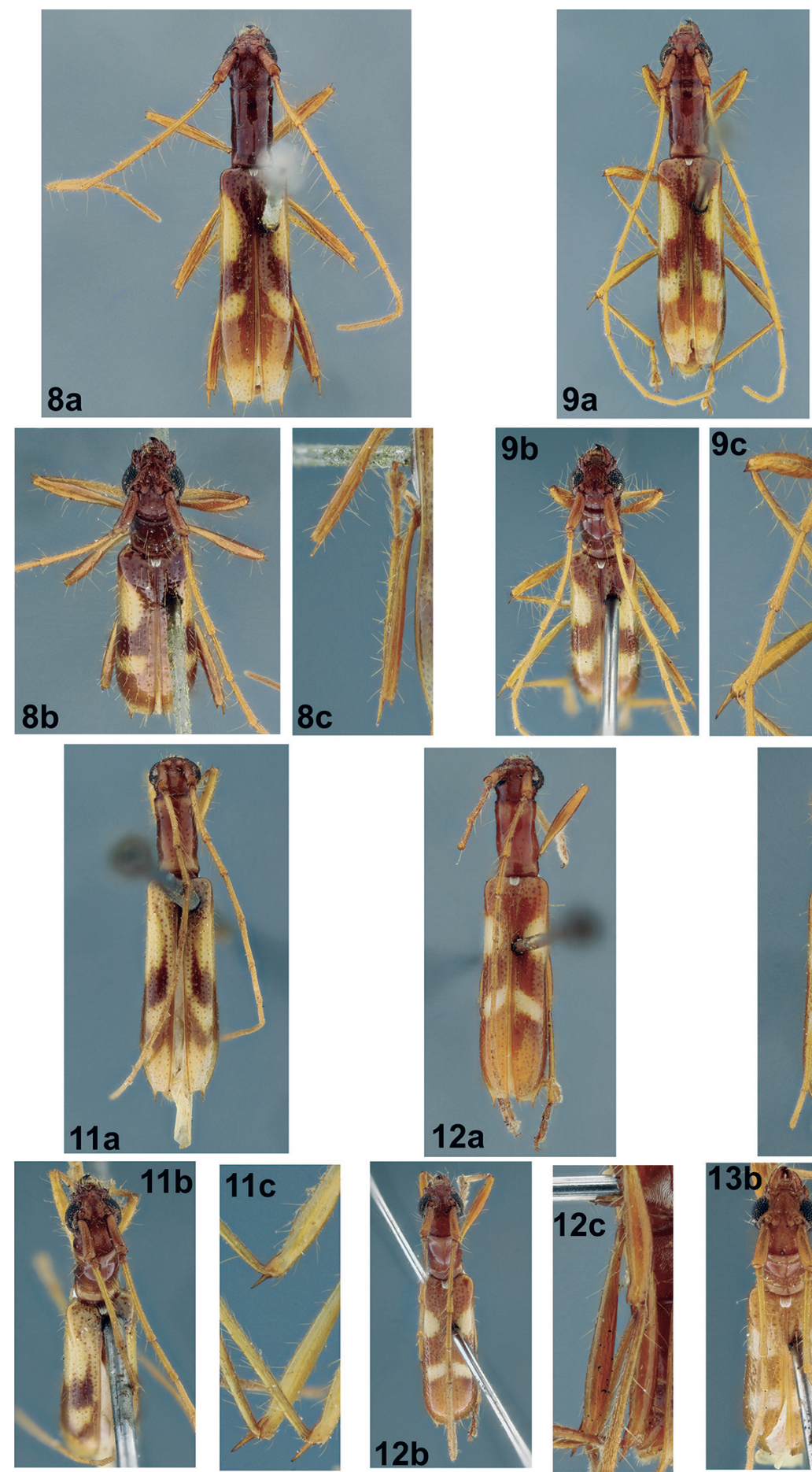
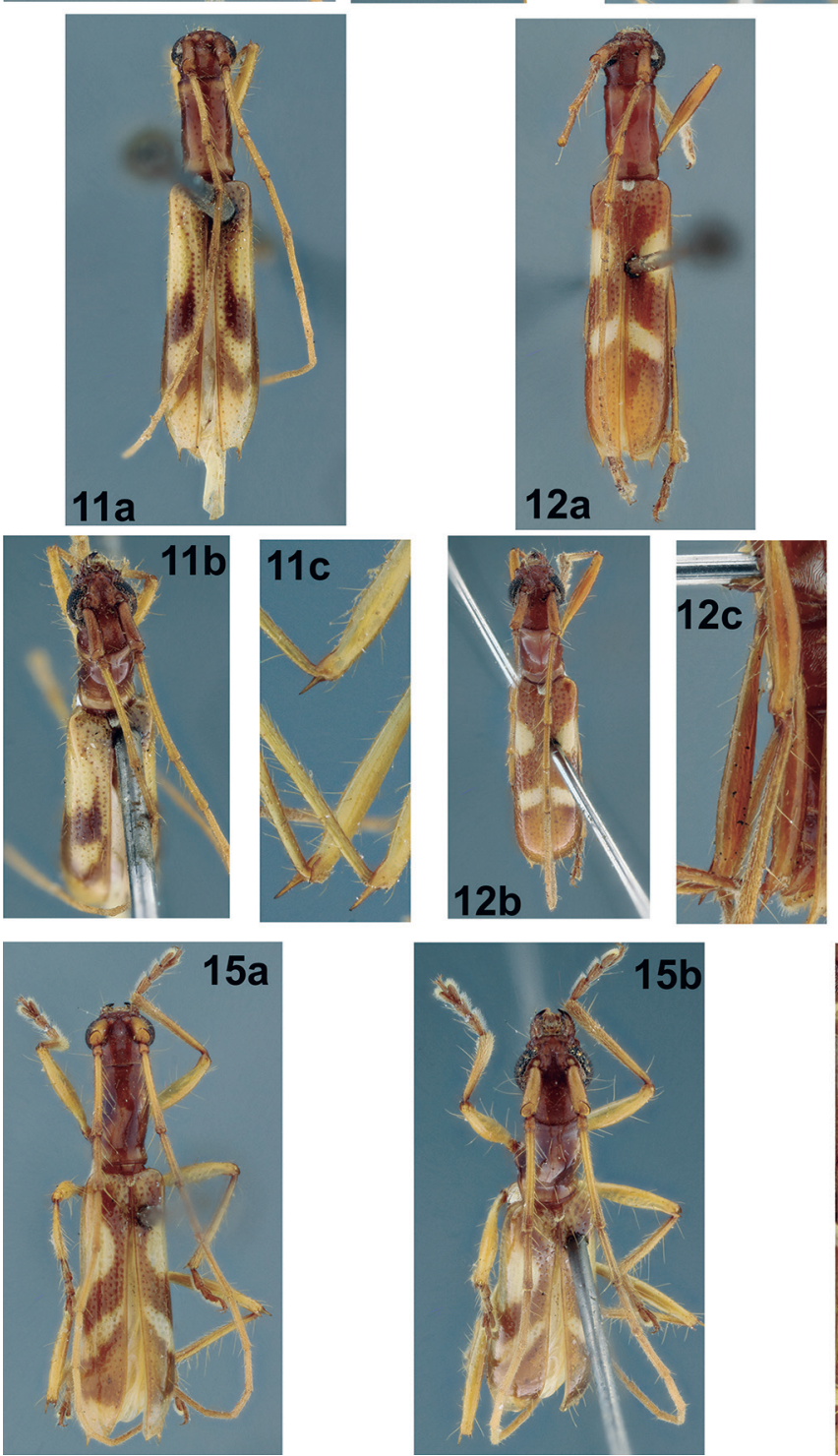

$5 b$

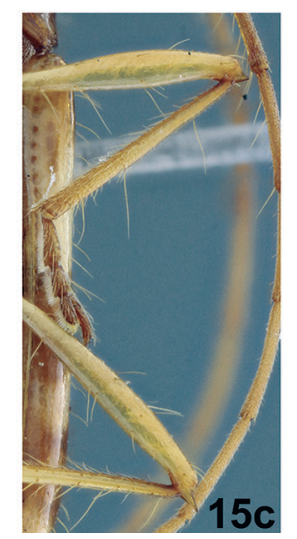

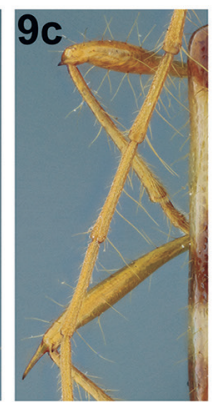
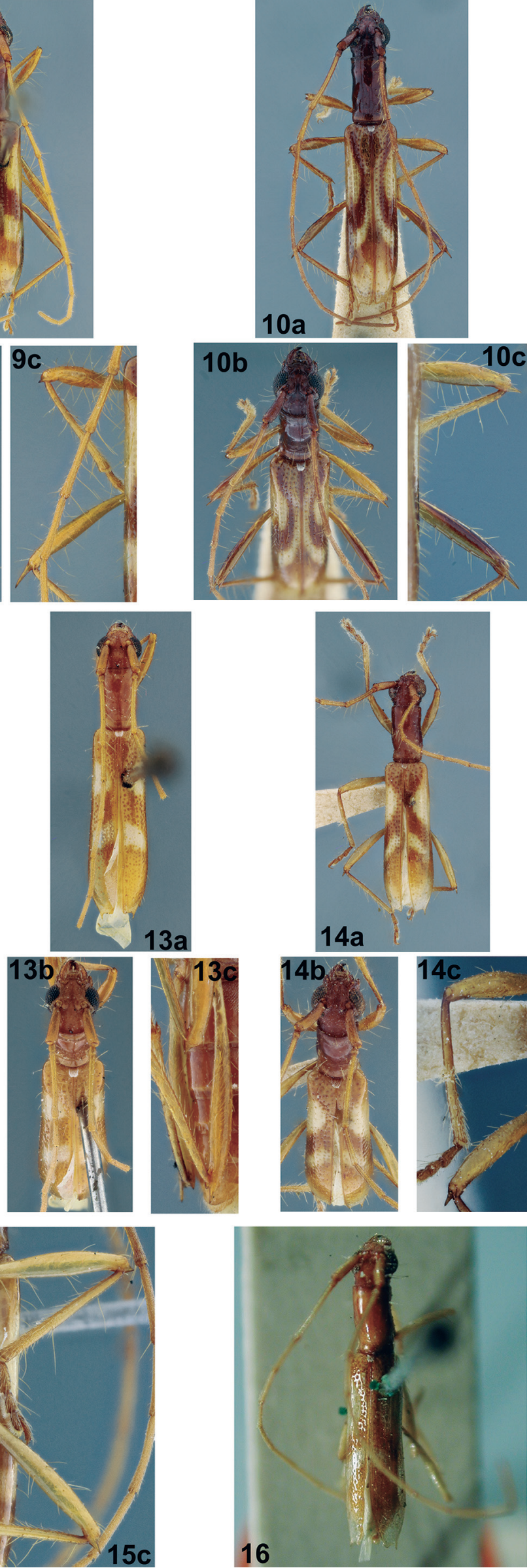

Figures 8-16. (8-15) Glyptoscapus pallidulus (a, dorsal habitus; b, anterodorsal view; c, meso- and metafemora): (8) Female; (9) Female; (10) Male; (11) Male; (12) Holotype female of G. vanettii; (13) Paratype female of G. vanettii; (14) Paratype of G. vanettii; (15) Male. (16) Holotype of G. pallidulus (photo by Larry G. Bezark). 

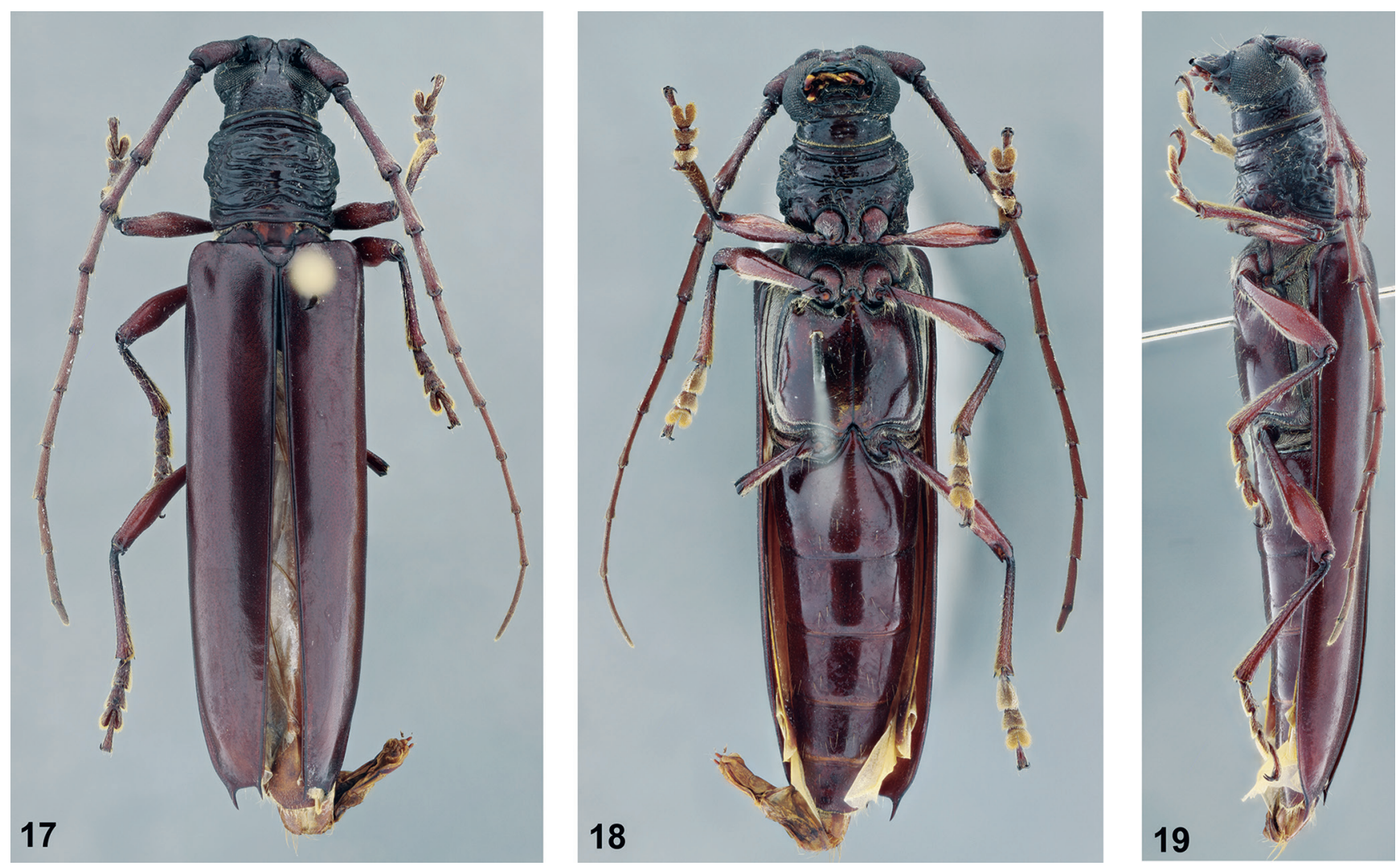

Figures 17-19. Coleoxestia rafaeli: (17) Dorsal habitus; (18) Ventral habitus; (19) Lateral habitus.

two at apex); distance between upper eye lobe 0.55 times length of scape; in frontal view, distance between lower eye lobes 0.53 times length of scape. Antennae 2.2 times elytral length, reaching elytral apex at distal third of antennomere VIII; scape finely, sparsely punctate, with short, sparse, decumbent whitish setae interspersed with long, erect, sparse yellowish-white setae; antennomeres III-V with long, erect pale yellow setae ventrally (shorter, sparser toward V); antennomeres VI-X with long, erect pale yellow setae at apex; antennal formula (ratio) based on length of antennomere III: scape $=0.53$; pedicel $=0.11 ; \mathrm{IV}=0.59 ; \mathrm{V}=0.61 ; \mathrm{VI}=0.60 ; \mathrm{VII}=0.65$; $\mathrm{VIII}=0.61 ; \mathrm{IX}=0.59 ; \mathrm{X}=0.55 ; \mathrm{XI}=0.74$.

Thorax: Prothorax 1.78 times longer than wide; sinuous in side view. Pronotum with fine, sparse punctures, from which emerge long erect yellowish setae; with minute, inconspicuous, sparse, decumbent, white setae. Sides of prothorax nearly smooth; with a few long, erect yellowish setae, and short, decumbent whitish setae close to procoxal cavity. Prosternum with V-shaped basal area with short, decumbent yellowish-white setae (more whitish depending on angle of light source), denser at centrobasal area; glabrous on remaining surface. Prosternal process noticeably narrowed centrally, and triangularly expanded distally. Ventral side of mesothorax with yellowish-white pubescence not obscuring integument (more whitish depending on angle of light source), but glabrous centrally on inclined area of mesoventral process. Mesoventral process distally cordiform. Metanepisternum and sides of metaventrite and area close to metacoxae with yellowish-white pubescence (more whitish depending on angle of light source), not obscuring integument; remaining surface of metaventrite with fine and coarse, sparse punctures, from which emerge long, erect yellowish setae. Scutellum with grayish-white pubescence on centrobasal area, golden, denser on remaining surface.

Elytra: Coarsely, moderately abundantly punctate on basal 2/3, finer, sparser on distal third; with slightly elevated carina from humerus to after middle; with long, erect yellowish-white setae emerging from some of the punctures, more abundant on distal half; apex excavated, with long spine at outer angle and rounded projection at sutural angle.

Legs: Femora with long, erect, sparse yellowish-white setae; profemora with short rounded lobe on outer and inner apex; mesofemora with long spine on inner apex, and rounded, not distinctly lobed on outer apex; metafemora with long spine on outer apex (longer than spine of mesofemora), and short, acute lobe on inner apex. Metatarsomere I slightly shorter than II-III together.

Abdomen: Ventrites I-IV with yellowish-white pubescence laterally (more whitish depending on angle of light source), very sparse, short yellowish-white setae centrally (especially on I-II), interspersed with a few long, erect yellowish setae. Ventrite $\mathrm{V}$ with abundant yellowish-white setae not obscuring integument, interspersed with long, erect yellowish setae on distal area; apex rounded. 
Dimensions in $\mathbf{m m}$ (holotype female): Total length, 9.95; prothoracic length, 2.25; basal prothoracic width, 1.20; distal prothoracic width, 1.30; humeral width, 1.85; elytral length, 6.25 .

Type material: Holotype female from BRAZIL, Minas Gerais: Parque Estadual do Rio Doce, 27.X-14.XI.2013, L. Migliore col. (MZSP).

Remarks: Glyptstocapus letiziae differs from G. cicatricosus by the dorsal and ventral sides of the body mostly very dark, and anterior yellow elytral macula small and not reaching the sides. In G. cicatricosus the general color is distinctly lighter and the elytral macula is larger and always reaches the sides (often margin).

Etymology: Named for our friend Letizia Janaína Migliore (MZSP), collector of the holotype.

\section{Key to the species of Glyptoscapus}

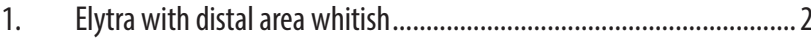

- Elytra without whitish distal area ........................................................ 3

2(1). Body mostly very dark, almost black; anterior yellowish macula of elytra not reaching epipleura. Brazil (Minas Gerais)

G. letiziae sp. nov.

- Body distinctly lighter dorsally and ventrally, with elytra at most partially brown on basal half; anterior yellowish macula of elytra reaching sides (often margin). Colombia, Peru, Bolivia, French Guiana, Brazil (Pará, Rondônia, Goiás, Bahia, Minas Gerais, Espírito Santo, Rio de Janeiro, São Paulo, Paraná), Argentina (Misiones)....... G. pallidulus (White, 1855)

3(1). Head darker than pronotum; elytra without dark area at apex (apex slightly lighter than basal area). Brazil (Minas Gerais)

G. bivittatus Gounelle, 1909

- Head lighter than most of pronotum; elytra with dark area at apex (darker than basal area). Colombia, Ecuador, Brazil (Amazonas, Pará)... ...G. flaveolus (Bates, 1870)

\section{Neoibidionini Monné, 2012}

\section{Thoracibidion io (Thomson, 1867) (New record)}

Ibidion (Tropidion) io Thomson, 1867: 141.

Thoracibidion io; Monné, 2018: 580; Tavakilian \& Chevillotte (2017).

Octoplon rugicolle Bates, 1870: 296.

Remarks: Thoracibidion io was originally described from Brazil (no detailed place indicated) and Octoplon rugicolle was described also from Brazil (Pará, Rio Tapajós). Martins (1968) synonymized the latter under T. io. Currently, T. io is recorded from Colombia, Venezuela, French Guiana, Suriname, Guyana, Peru, and Brazil (Amazonas, Pará, Pernambuco, Espírito Santo, Rio de Janeiro) (Monné, 2018). We are adding the Brazilian state of Alagoas as a new record.
Material examined: BRAZIL, Alagoas: Murici, 1 female, Nancy col. (MZSP).

\section{Cerambycini Latreille, 1802}

\section{Coleoxestia denticornis (Gahan, 1892) (New record)}

Xestia denticornis Gahan, 1892: 29.

Coleoxestia denticornis; Aurivillius, 1912: 64 (cat.); Monné (2018): 85; Tavakilian \& Chevillotte (2017).

Remarks: Species widely distributed in Brazil and also registered for Bolivia and Paraguay.

Material examined: BRAZIL, Alagoas: Murici, 1 female and 3 males (MZSP).

\section{Coleoxestia rafaeli Santos-Silva \& Wappes, 2017 (New record) (Fig. 17-19)}

Coleoxestia rafaeli; Santos-Silva \& Wappes (2017): 11; Monné (2018): 89; Tavakilian \& Chevillotte (2017).

Coleoxestia rafaeli is known from Brazil in the states of Paraná (holotype) and Santa Catarina (paratype). We found 14 specimens of this species from São Paulo. We are describing the female of this species for the first time.

Description: Female: Antennae 1.1 times as long as elytra (about 1.5 times in male), reaching about distal quarter of elytra (surpassing elytral apex at least by antennomere $\mathrm{XI}$ in male), and abdominal ventrite $\mathrm{V}$ with sides distinctly convergent toward truncate apex (slightly emarginate centrally), slightly shorter than IV (less distinctly narrowed toward apex, which is wider in male). Antennal formula (ratio) based on length of antennomere III: scape $=0.57$; pedicel $=0.11 ; \mathrm{IV}=0.58 ; \mathrm{V}=0.62 ; \mathrm{VI}=0.60$; $\mathrm{VII}=0.59 ; \mathrm{VIII}=0.58 ; \mathrm{IX}=0.54 ; \mathrm{X}=0.45 ; \mathrm{XI}=0.79$.

Dimensions in $\mathbf{~ m m}$ (female): Total length, 30.0; prothoracic length, 4.5; basal prothoracic width, 4.7; distal prothoracic width, 3.9; humeral width, 6.7; elytral length, 22.6.

Remarks: The female differs from male by the shorter antennae. The antennomere III is not distinctly angulate at outer side, but it is notably angulate in the holotype and paratype males. However, we examined a male from the Brazilian state of São Paulo with antennomere III as in the female (not distinctly angulate at outer side). Consequently, the outer apex of the antennomere III in C. rafaeli, although never nodose, is somewhat variable.

Material examined (all from MZSP): BRAZIL, São Paulo: Luiz Antonio (Est. Ecológica Jatai, Mata ciliar, 21 ${ }^{\circ} 36^{\prime} 47^{\prime \prime} S$ $\left.47^{\circ} 43^{\prime} 43^{\prime \prime} \mathrm{W}\right), 1$ female and 8 males, XII.2008, Laura \& Perioto col.; 1 male, II.2009, 5 males, XI.2008. 


\section{ACKNOWLEDGMENTS}

We express our sincere thanks to Letizia Janaína Migliore for donating the holotype to the MZSP collection. We are very grateful to Mr. Larry Bezark for his friendship, for revising the manuscript and for allowing the use of the images of his website, to Dr. Keith $M$ Bayless and Dr. Simone Policena Rosa (Universidade Federal de Itajubá, Minas Gerais, Brazil) for the valuable corrections and improvements in the manuscript. The first author thanks the grant 2017/15283-9, São Paulo Research Foundation (FAPESP).

\section{REFERENCES}

Aurivillius, C. 1899. Neue oder wenig bekannte Coleoptera Longicornia. 6. Entomologisk Tidskrift, 20: 259-265.

Aurivillius, C. 1912. Cerambycidae: Cerambycinae Coleopterorum Catalogus pars 39, Berlin, W. Junk \& S. Schenkling. v. 22, 574p.

Bates, H.W. 1870. Contributions to an insect fauna of the Amazon Valley (Coleoptera: Cerambycidae). The Transactions of the Entomological Society of London, 1870: 243-335.

Bezark, L.G. 2018. A photographic Catalog of the Cerambycidae of the New World. Available at: https://apps2.cdfa.ca.gov/publicApps/plant/ bycidDB/wsearch.asp?w=n. Access in: 02/2018.

Gahan, C.J. 1892. Notes on Longicorn Coleoptera of the Group Cerambycinæ, with Descriptions of new Genera and Species. The Annals and Magazine of Natural History, Ser. 6, 9: 19-32.

Gounelle, E. 1909. Liste des cérambycides de la région de Jatahy, Etat de Goyaz, Brésil. Annales de la Société Entomologique de France, 77: 587-688.
Lawrence, J.F.; Beutel, R.G.; Leschen, R.A.B. \& Ślipiński, A. 2010. Glossary of morphological terms. In: Leschen R.A.B.; Beutel R.G. \& Lawrence J.F. (Eds.). Handbook of Zoology, Coleoptera, Beetles, Vol. 2: Morphology and Systematics (Elateroidea, Bostrichiformia, Cucujiformiapartim). Berlin, Walter de Gruyter, p. 9-20.

Martins, U.R. 1959. Ibidionini (Coleoptera, Cerambycinae) I. Gêneros de escapo cicatricoso. Papéis Avulsos do Departamento de Zoologia, 13(22): 265-273.

Martins, U.R. 1967. Monografia da tribo lbidionini (Coleoptera, Cerambycinae). Parte I. Arquivos de Zoologia, 16(1): 1-320.

Martins, U.R. 1968. Monografia da tribo lbidionini (Coleoptera, Cerambycinae). Parte II. Arquivos de Zoologia, 16(2): 321-630.

Martins, U.R. 2006. Tribo Hexoplonini, pp. 21-211. In: Martins, U.R. (Org.). Cerambycidae Sul-Americanos (Coleoptera). Taxonomia. Volume 8. Curitiba, Sociedade Brasileira de Entomologia. ii + 234 pp.

Monné, M.A. 2018. Catalogue of the Cerambycidae (Coleoptera) of the Neotropical Region. Part I. Subfamily Cerambycinae. Available at: http://cerambyxcat.com/Parte1 Cerambycinae 2018.pdf. Access in: 02/2018.

Santos-Silva, A. \& Wappes, J.E. 2017. Six new species and a new country record of Coleoxestia Aurivillius, 1912 (Coleoptera, Cerambycidae, (erambycinae). Insecta Mundi, 0572: 1-19.

Tavakilian, G. \& Chevillotte, H. 2017. Titan: base de données internationales sur les Cerambycidae ou Longicornes. Available at: http://titan.gbif.fr/index. html. Access in: 02/2018.

Thomson, J. 1867. Ibidionitarumspeciesnovae. Physis Recueil d'Histoire Naturelle, 1(3): 133-163.

White, A. 1855. Catalogue of the Coleopterous Insects in the collection of the British Museum, London, 8: 175-412. 